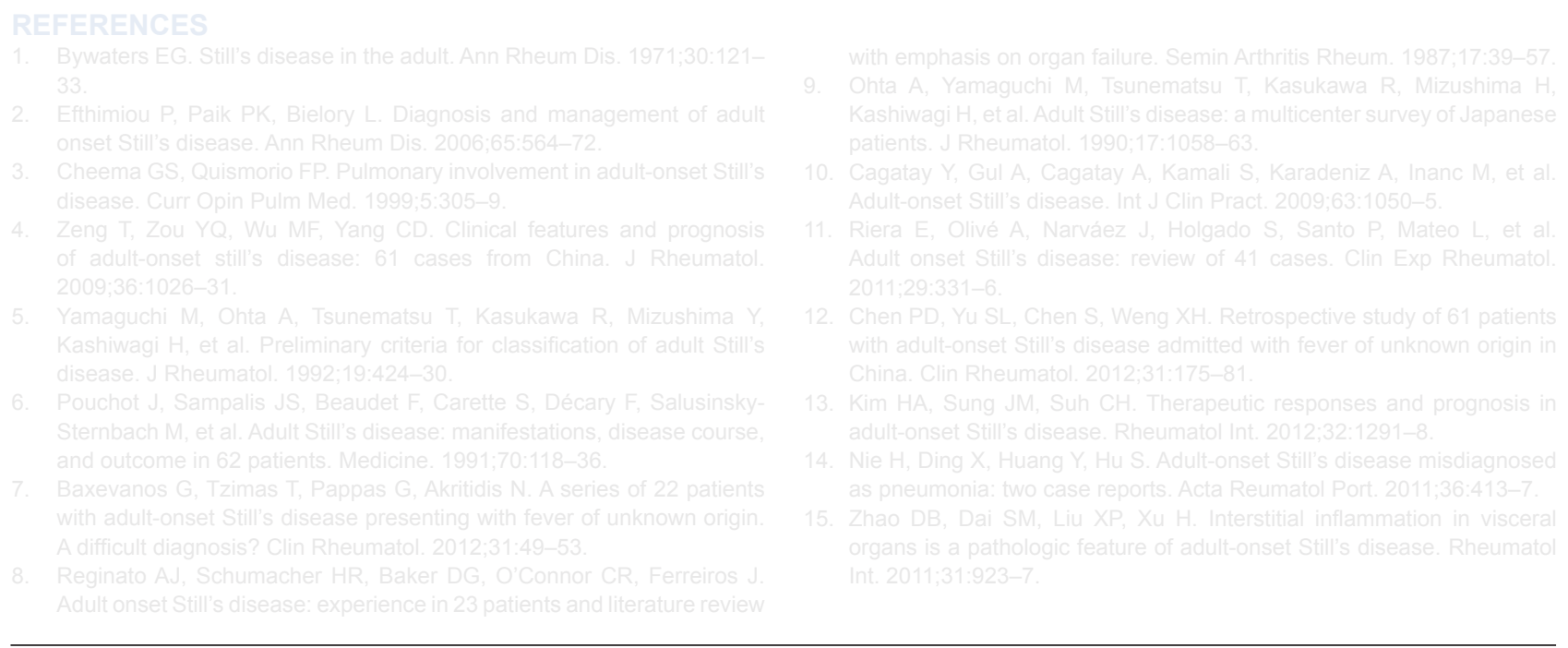

\title{
Family Phenotypic Heterogeneity Caused by Mitochondrial DNA Mutation A3243G
}

\section{Heterogeneidade Fenotípica de uma Família Causada pela Mutação no ADN Mitocondrial A3243G}

\author{
Daniela ALVES $\mathbb{1}^{1}$, Maria Eufémia CALMEIRO ${ }^{1}$, Carmo MACÁRIO $^{2}$, Rosa SILVA ${ }^{1}$ \\ Acta Med Port 2017 Jul-Aug;30(7-8):581-585 - https://doi.org/10.20344/amp.8638
}

\section{ABSTRACT}

Maternally inherited diabetes and deafness is a rare form of diabetes caused by a mitochondrial DNA mutation. The index case is a 55-year-old woman who was admitted with hypertrophic cardiomyopathy. She had a history of diabetes mellitus and hearing loss. The patient's mother, two brothers and two sisters also had a history of diabetes and hearing loss. This pattern suggests a maternally inherited disorder. All siblings carried the A3243G mitochondrial DNA mutation. The identification of people with monogenic forms of diabetes mellitus is a diagnostic challenge. This condition should be considered whenever there is a history of diabetes associated with hearing loss and a relevant family history. Cardiopathy is also known to be an important feature of mitochondrial disease. In order to identify this aetiology, family screening, genetic counselling and screening of associated comorbidities are encouraged.

Keywords: Child; Deafness/genetics; Diabetes Mellitus/genetics; DNA, Mitochondrial/genetics; Mutation

\section{RESUMO}

A síndrome diabetes e surdez de transmissão materna é uma forma rara de diabetes que resulta da mutação A3243G do ADN mitocondrial. Expõe-se o caso de uma doente do sexo feminino, 55 anos de idade, admitida por cardiomiopatia hipertrófica. A doente possui antecedentes de diabetes mellitus e surdez. Da história familiar, destaca-se a mãe e os seus dois irmãos e duas irmãs, que apresentam diabetes e surdez. Este padrão sugere uma doença de herança maternal. Todos são portadores da mutação A3243G do ADN mitocondrial. A identificação de pessoas com formas monogénicas de diabetes mellitus é um desafio diagnóstico. Deve ser considerado sempre que há história de diabetes associada a surdez e história familiar de diabetes. A cardiomiopatia hipertrófica é uma característica importante da patologia mitocondrial. Nestes doentes deve ser considerada a avaliação da família, aconselhamento genético e triagem de comorbilidades associadas.

Palavras-chave: Criança; Diabetes Mellitus/genética; DNA Mitocondrial/genética; Mutação; Surdez/genética

\section{INTRODUCTION}

Diabetes mellitus (DM) and its clinical features may arise as a result of genetic disorders. ${ }^{1}$ Mitochondrial diabetes encompasses a group of pathologies that are caused by a dysfunction of the mitochondrial respiratory chain. ${ }^{2}$

Maternally inherited diabetes and deafness (MIDD) is a rare form of DM. The most common mutation in MIDD results from the presence of an $A$ instead of a $G$ in the position 3243 (A3243G) of the mitochondrial DNA (mtDNA) that encodes the gene for tRNA. Other mitochondrial DNA point mutations have been associated with MIDD, but are extremely rare. $^{2}$

The condition is maternally inherited as mitochondrial DNA is practically only derived from oocytes. ${ }^{3}$ Some pathophysiological mechanisms that may lead to

1. Serviço de Medicina Interna. Hospital Amato Lusitano. Castelo Branco. Portugal.

2. Serviço de Neurologia. Centro Hospitalar e Universitário de Coimbra. Coimbra. Portugal.

$\triangle$ Autor correspondente: Daniela Alves. dmdalves11@hotmail.com

Recebido: 07 de janeiro de 2017 - Aceite: 27 de março de 2017 | Copyright @ Ordem dos Médicos 2017 
mitochondrial diabetes include impaired insulin secretion, glucose toxicity with loss of pancreatic cells, and insulin resistance. $^{4}$

First described in 1992, MIDD affects $0.5 \%$ to $2.8 \%$ of people with diabetes. Patients typically have progressive insulinopenia, sensorineural hearing loss and macular dystrophy. ${ }^{5-7}$ Unfortunately, MIDD often goes unrecognised. ${ }^{5}$

A multicentre study by Guilasseau et al showed that all patients with MIDD experienced neurosensory hearing loss and $86 \%$ had macular dystrophy. ${ }^{5}$ Surprisingly, the prevalence of diabetic retinopathy was lower than expected $(8 \%)$ while the prevalence of kidney disease was as high as $28 \%$. $^{7}$

The present clinical report describes a case of a person with diabetes who was admitted because of an associated comorbidity. A thorough clinical and family history study suggested the diagnosis of MIDD, which was subsequently confirmed.

\section{CASE REPORT}

The index case (II.4) is a 55-year-old woman who went to the emergency room because of chest pain, dyspnoea and fatigue. She had been diagnosed with diabetes 12 years earlier, and suffered from progressive sensorineural hearing loss. Diabetes was non-insulin dependent at onset, but 11 years later she started insulin therapy. Her body mass index (BMI) was $21 \mathrm{~kg} / \mathrm{m}^{2}$.

The patient was admitted to the hospital. A crosssectional echocardiography showed hypertrophy of the left ventricle, with a left ventricular ejection fraction of $42 \%$. Hypertrophic cardiomyopathy was diagnosed. She was then referred to the internal medicine department because of multisystem comorbidities and to follow-up her diabetes. She also had a history of depression, cognitive impairment and progressive loss of motor skills.

While recording the patient's family history, it became evident that she, her mother and her four siblings shared a history of diabetes and progressive deafness. Her family is represented in the family tree in Fig. 1.

The presence of diabetes, deafness and a relevant family history prompted an investigation for MIDD. The genetic test was performed in blood leukocytes and showed A3243G mitochondrial DNA mutation. The index case's (II.4) siblings carried A3243G mitochondrial DNA mutation with different heteroplasmy levels.

One of the index case's sisters (II.5) presented signs of depression and cognitive impairment. A brain magnetic resonance imaging $(\mathrm{MRI})$ revealed calcification of basal ganglia and diffuse atrophy of the cerebellum. These are common features of mitochondrial disorders (Fig.s 2, 3).

The index case (II.4) and her sister (II.5) underwent an ophthalmologic examination, which revealed macular dystrophy (Fig. 4). Moreover, their hearing tests showed sensorineural deafness with preponderance to high frequencies. Their blood and urine tests showed proteinuria with preserved renal function.

Moreover, a muscular biopsy showed ragged red fibres (H-E) that were simultaneously active to succinate dehydrogenase (SDHase) and COX-negatives (COX), which is specific to mitochondrial disorders (Fig. 5).

After a detailed family history study and counselling, genetic testing was offered to the patients and their firstdegree relatives. The III.1, III.2 and III.3 cases, who were all under 30 years old, agreed to participate in genetic screening, and the result was a positive test for A3243G mitochondrial DNA mutation. They were referred to genetic counselling. Currently, none of them shows signs of the disease.

Family phenotypic heterogeneity is represented in Table 1. This family is an example of the multiorgan involvement of mitochondrial diseases.

\section{DISCUSSION}

Monogenic forms of DM are difficult to diagnose. After being diagnosed, patients should be closely followed because of distinctive management issues and associated

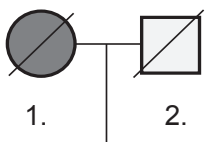

Manifestation definitions

I

1.

2.

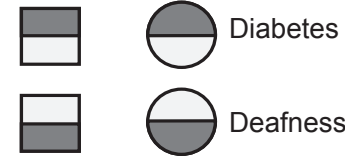

II

1. (60)

III

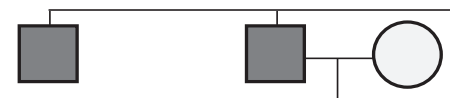

2. (58)

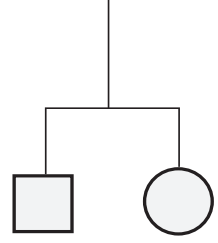

1.
2

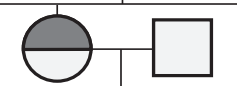

3. (57)

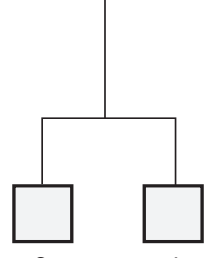

3.

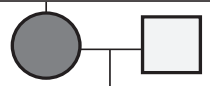

4. (55)

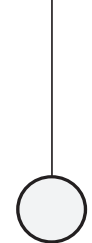

5. (29)

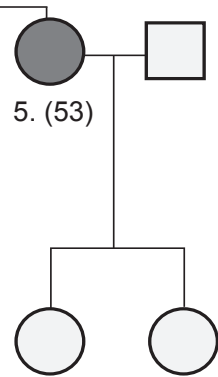

6. (26)

7. (23)

Figure 1 - Index case family tree 


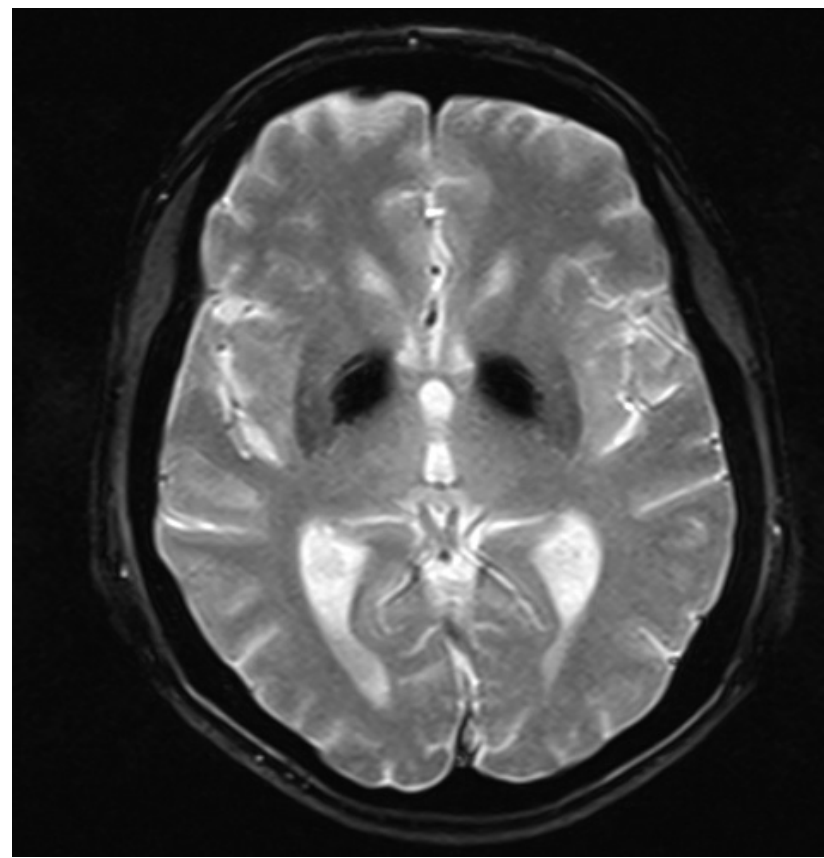

Figure 2 - Sequence T2 GE in the axial plane. This sequence is very sensitive to material with magnetic susceptibility, namely minerals such as calcium and blood (hyposignal)

\section{comorbidities..$^{6,8}$}

MIDD usually manifests itself in organs with a higher metabolic rate. The main diagnostic features may be accompanied by a wide range of manifestations that result from cellular energy deficiency. ${ }^{2}$

Diverse levels of mutated mtDNA in different tissues result in different phenotypic expressions of MIDD. On the other hand, heteroplasmy levels can potentially determine MIDD phenotype's severity. . $^{9,10}$ This mutation can also result in a more severe syndrome - MELAS (mitochondrial myopathy, encephalopathy, lactic acidosis and stroke), and, thus, its differential diagnosis is very important. ${ }^{9}$ The index case (II.4) and her family did not present the landmark clinical manifestations of MELAS - lactic acidosis or strokelike episodes.

A strong familial clustering of diabetes should raise

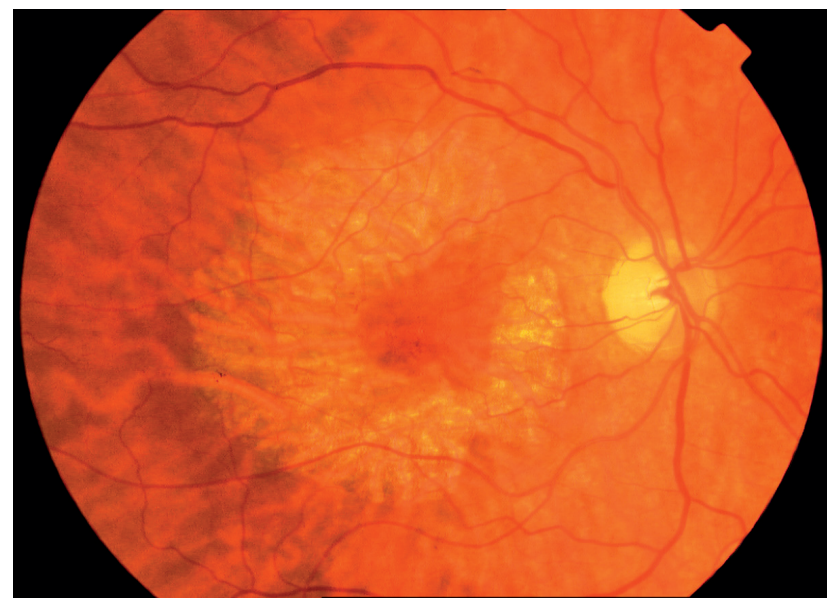

Figure 4 - Macular dystrophy present in index case

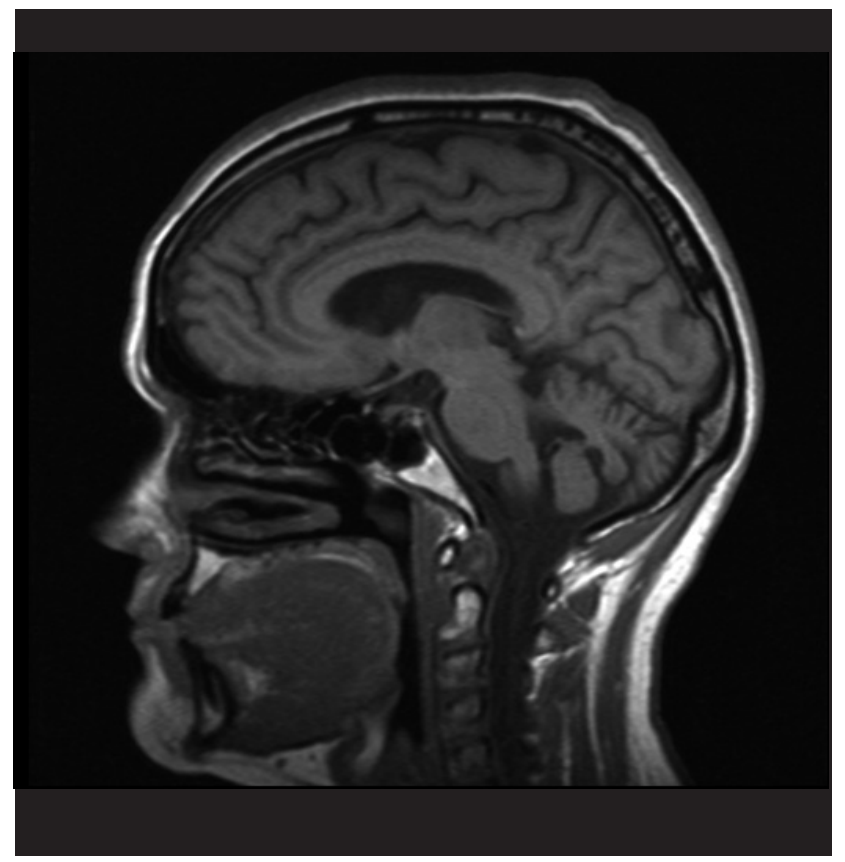

Figure 3 - Sequence T1 SE in the sagittal plane, showing enlargement of the folia of the cerebellum, which presents a lower volume than expected for the age group

the suspicion of mitochondrial diabetes. It may also indicate MODY (maturity onset diabetes of the young), but the presence of maternal transmission together with hearing impairment or macular dystrophy distinguishes mitochondrial diabetes from MODY. ${ }^{8}$

Persistent hyperglycaemia leads to both mitochondrial dysfunction and reduced insulin release. The estimated penetrance of diabetes is $85 \% .^{2}$ The average age for the onset of diabetes, which is usually insidious, ranges between 30 and 40 years old. The index case (II.4) was diagnosed with diabetes at the age of 33 and had a normal BMI. She also had high heteroplasmy levels. A significant negative correlation was found between heteroplasmy levels and BMI: the lower the BMI, the higher the heteroplasmy levels. ${ }^{9}$ MIDD's most common ophthalmic feature is macular retinal dystrophy, which affects $86 \%$ of cases. ${ }^{5}$ The index case (II.4)

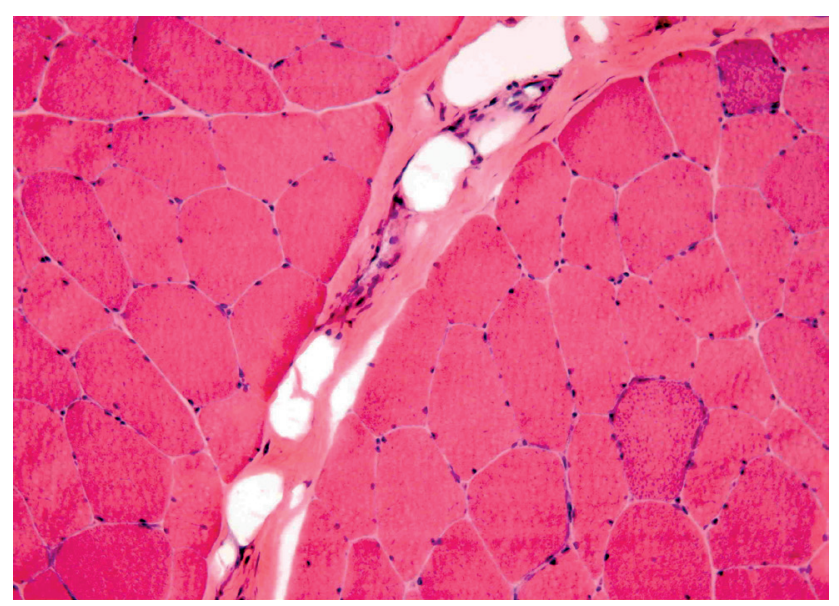

Figure 5 - Muscular biopsy with ragged red fibres, hematoxylin eo$\sin (\mathrm{H}-\mathrm{E})$ 
Table 1 - Family phenotypic heterogeneity

\begin{tabular}{|c|c|c|c|c|c|c|c|c|c|}
\hline & Gender & Age & $\begin{array}{c}\text { Heteroplasmy } \\
\% \text { A3243G } \\
\text { mtDNA }\end{array}$ & Deafness & Diabetes & $\begin{array}{l}\text { Macular } \\
\text { dystrophy }\end{array}$ & $\begin{array}{l}\text { Neuropsychiatric } \\
\text { symptoms }\end{array}$ & $\begin{array}{l}\text { Cardiac } \\
\text { disorders }\end{array}$ & Nephropathy \\
\hline I.1 & $\mathrm{F}$ & $\begin{array}{l}\text { Dead } \\
\text { at } 82\end{array}$ & Unknown & Yes & Yes & Unknown & Unknown & Unknown & Unknown \\
\hline II.1 & M & 60 & $58 \%$ & Yes & Yes & Yes & $\begin{array}{l}\text { Developmental } \\
\text { cognitive delay from } \\
\text { birth }\end{array}$ & - & - \\
\hline II.2 & $M$ & 58 & $21 \%$ & Yes & Yes & - & - & $\begin{array}{l}\text { Left fascicular } \\
\text { block }\end{array}$ & - \\
\hline II.3 & $F$ & 57 & $11 \%$ & Yes & Yes & - & - & $\begin{array}{l}\text { Hypertrophic } \\
\text { cardiomyopathy }\end{array}$ & - \\
\hline II.4 & $\mathrm{F}$ & 55 & $52 \%$ & Yes & $\begin{array}{l}\text { Insulin } \\
\text { therapy }\end{array}$ & Yes & Depression & $\begin{array}{c}\text { Hypertrophic } \\
\text { cardiomyopathy; } \\
\text { left anterior } \\
\text { fascicular block }\end{array}$ & Proteinuria \\
\hline II.5 & $\mathrm{F}$ & 53 & $44 \%$ & Yes & $\begin{array}{l}\text { Insulin } \\
\text { therapy }\end{array}$ & Yes & $\begin{array}{l}\text { Cognitive } \\
\text { dysfunction; } \\
\text { Depression }\end{array}$ & $\begin{array}{l}\text { Hypertrophic } \\
\text { cardiomyopathy }\end{array}$ & Proteinuria \\
\hline III.1 & $\mathrm{F}$ & 29 & $51 \%$ & - & - & - & - & - & - \\
\hline III.2 & $\mathrm{F}$ & 26 & $43 \%$ & - & - & - & - & - & - \\
\hline III.3 & $\mathrm{F}$ & 23 & $<5 \%$ & - & - & - & - & - & - \\
\hline
\end{tabular}

complained of visual loss and night blindness. Macular test images show pigmented lesions in the retina and atrophy of the choroid pigment epithelium, with "salt and pepper" appearance, as can be seen in Fig. 4.

Brain changes (i.e., bilateral subcortical and basal ganglia high-signal lesions on T2-weighted images) appear in the MRI of case II.5. These changes probably reflect a hypometabolic state in neurons caused by mitochondrial respiratory function impairment. ${ }^{2}$ Both $\mathrm{II} .5$ and II.1 have neuropsychiatric disorders with depression and show progressive cognitive dysfunction since birth.

Nephropathy is more common in people with MIDD, suggesting a specific involvement of mitochondrial kidney disease. ${ }^{7}$ Blood pressure control and early treatment with nephroprotective agents may be beneficial to prevent renal failure. ${ }^{11}$

Cardiopathy is known as another important feature of mitochondrial disease. Hypertrophic remodelling is the dominant pattern of cardiomyopathy in all forms of mitochondrial disease, occurring in up to $40 \%$ of patients. ${ }^{12}$ Follow-up and screening of both cardiac conduction abnormalities and heart failure must be conducted regularly from an early stage.

Some drugs such as tetracyclines, valproate and metformin may deteriorate mitochondrial function; however, their effects in MIDD patients are not well-known. Metformin is less effective and may be harmful because of the increased risk of lactic acidosis.

There is no curative treatment for patients with mitochondrial disease. Given the lack of treatments and the limitations of prenatal and preimplantation diagnosis, attention has focused on prevention of transmission of mitochondrial disease through germline gene replacement therapy. ${ }^{13,14}$

\section{CONCLUSION}

The identification of monogenic forms of DM is difficult. However, this condition should be considered whenever there is a history of diabetes associated with both hearing loss and relevant family history. All first-degree family members should be screened for the mutation and provided with genetic counselling. The diagnosis of mitochondrial disorder can influence treatment options for diabetes.

\section{PROTECTION OF HUMANS AND ANIMALS}

The authors declare that the procedures were followed according to the regulations established by the Clinical Research and Ethics Committee and to the Helsinki Declaration of the World Medical Association.

\section{DATA CONFIDENTIALITY}

The authors declare having followed the protocols in use at their working center regarding patients' data publication.

\section{CONFLICTS OF INTEREST}

All authors report no conflict of interest.

\section{FUNDING SOURCES}

This research received no specific grant from any funding agency in the public, commercial, or not-for-profit sectors. 


\section{REFERENCES}

1. Kadowaki T, Kadowaki H, Mori Y, Tobe K, Sakuta R, Suzuki Y, et al. A subtype of diabetes mellitus associated with a mutation of mitochondrial DNA. N Engl J Med. 1994;330:962-8.

2. Murphy R, Turnbull DM, Walker M, Hattersley AT. Clinical features, diagnosis and management of maternally inherited diabetes and deafness (MIDD) associated with the $3243 A>G$ mitochondrial point mutation. Diabet Med. 2008;25:383-99.

3. Meas $T$, Laloi-Michelin M, Virally M, Ambonville $C$, Kevorkian JP, Guillausseau PJ. Diagnostic clinique et biologique du diabète mitochondrial et particularités de sa prise en charge. Rev Med Interne. 2010;31:216-21.

4. Brandle M, Lehmann R, Maly FE, Schmid C, Spinas GA. Diminished insulin secretory response to glucose but normal insulin and glucagon secretory responses to arginine in a family with maternally inherited diabetes and deafness caused by mitochondrial tRNA(LEU(UUR)) gene mutation. Diabetes Care. 2001;24:1253-8.

5. Guillausseau PJ, Massin P, Dubois-LaForgue D, Timsit J, Virally M, Gin $H$, et al. Maternally inherited diabetes and deafness: a multicenter study. Ann Intern Med. 2001;134:721-8.

6. Donovan LE, Severin NE. Maternally inherited diabetes and deafness in a North American kindred: tips for making the diagnosis and review of unique management issues. J Clin Endocrinol Metab. 2006;91:4737-42.

7. Massin P, Dubois-Laforgue D, Meas T, Laloi-Michelin M, Gin H, Bauduceau B, et al. Retinal and renal complications in patients with a mutation of mitochondrial DNA at position 3,243 (maternally inherited diabetes and deafness). A case-control study. Diabetologia. 2008;51:1664-70.

8. Naing A, Kenchaiah M, Krishnan B, Mir F, Charnley A, Egan C, et al Maternally inherited diabetes and deafness (MIDD): diagnosis and management. J Diabetes Complications. 2014;28:542-6.

9. Laloi-Michelin M, Meas T, Ambonville C, Bellanné-Chantelot C, Beaufils $\mathrm{S}$, Massin P, et al. The clinical variability of maternally inherited diabetes and deafness is associated with the degree of heteroplasmy in blood leukocytes. J Clin Endocrinol Metab. 2009;94:3025-30.

10. de Wit HM, Westeneng HJ, van Engelen BG, Mudde AH. MIDD or MELAS: that's not the question MIDD evolving into MELAS: a severe phenotype of the m.3243A>G mutation due to paternal co-inheritance of type 2 diabetes and a high heteroplasmy level. Neth J Med. 2012;70:4602.

11. Fischel-Ghodsian N. Mitochondrial DNA mutations and diabetes: another step toward individualized medicine. Ann Intern Med. 2001;134:777-9.

12. Bates MG, Bourke JP, Giordano C, d'Amati G, Turnbull DM, Taylor RW. Cardiac involvement in mitochondrial DNA disease: clinical spectrum, diagnosis, and management. Eur Heart J. 2012;33:3023-33.

13. DiMauro S, Mancuso M. Mitochondrial diseases: therapeutic approaches. Biosci Rep. 2007;27:125-37.

14. Amato P, Tachibana M, Sparman M, Mitalipov S. Three-parent in vitro fertilization: gene replacement for the prevention of inherited mitochondrial diseases. Fertil Steril. 2014;101:31-5. 